\title{
Nanopyramid Formation by Ag Metal-Assisted Chemical Etching for Nanotextured Si Solar Cells
}

\author{
Bhaskar Parida, Jaeho Choi, Srikanta Palei, and Keunjoo Kim ${ }^{\dagger}$ \\ Department of Mechanical Engineering and Research Center of Industrial Technology, Chonbuk National University, \\ Jeonju 54896, Korea
}

Seung Jong Kwak

Division of R\&D, Withlight Co., Ltd., Jeonju 54852, Korea

Received June 22, 2015; Revised July 23, 2015; Accepted August 5, 2015

\begin{abstract}
We investigated the formation of a nanopyramidal structure and fabricated nanotextured Si solar cells using an Ag metal-assisted chemical etching process. The nanopyramidal structure was formed on a Si flat surface and the nanotexturing process was performed on the p-type microtextured Si surface. The nanostructural formation shows a transition from nanopits and nanopores to nanowires with etching time. The nanotextured surfaces also showed the photoluminescence spectra with an enhanced intensity in the wavelength range of 1,100 1,250 nm. The photoreflectance of the nanotextured Si solar cells was strongly reduced in the wavelength range of 337 596 $\mathrm{nm}$. However, the quantum efficiency is decreased in the nanotextured samples due to the increased nanosurface recombination. The nanotexturing process provides a better $\mathrm{p}-\mathrm{n}$ junction impedance of the nanotextured cells, resulting in an enhanced shunt resistance and fill factor which in turn renders the possibility of the increased conversion efficiency.
\end{abstract}

Keywords: Metal assisted chemical etching, Si solar cells, Nanotexturing, Nanopyramids

\section{INTRODUCTION}

The surface texturization of Si solar cells has an important role in reducing the photoreflectance (PR) losses and increasing the photoabsorption of the cells to improve the overall electrical characteristics such as short-circuit current $\left(\mathrm{I}_{\mathrm{sc}}\right)$, open-circuit voltage $\left(\mathrm{V}_{\mathrm{oc}}\right)$, and conversion efficiency [1-3]. However, the textured surfaces are also inefficient in reducing the PR to less than $10 \%$. Therefore, $\mathrm{SiN}_{\mathrm{x}}$ as an anti-reflection coating (ARC) layer has been deposited on solar cells to reduce the PR and act as a surface passivation layer; however, it exhibits narrow acceptance of the incident light due to the destructive interference of the

${ }^{\dagger}$ Author to whom all correspondence should be addressed: E-mail:kimk@chonbuk.ac.kr

Copyright $(2015$ KIEEME. All rights reserved. This is an open-access article distributed under the terms of the Creative Commons Atribution Non-Commercial
License (httr:///creativecommons.org/licenses/by-nc/3, o) which permits unrestricted noncommercial use, License (hitp://) reativecommons.org/licenses/by-nc/3.o) which permits unrestricted
distribution, and reproduction in any medium, provided the original work is properly cited reflected light [4]. Further, several nanostructures have been implemented in order to improve the light absorption of solar cells by wave diffraction effect, which can efficiently transmit light into the Si solar cells and enhance the shunt resistance of pn junction [5-7]. Among these nanostructures, nanotextured black Si solar cells have attracted considerable attention due to their low reflectivity over a wide spectral range that improves conversion efficiency to over $18 \%$ [8-10].

Several methods have been developed for the nanotexturing of the Si solar cell surface including laser texturing, reactive ion etching (RIE), nanoimprint lithography, and metal assisted chemical etching (MACE) [11-15]. Due to the high cost and process complexity of RIE, laser texturization, and nanoimprint lithography, their applications in Si solar cells are limited. Therefore, metal assisted chemical etching has been investigated to obtain nanotextured Si solar cells due to its low cost and simple fabrication process over a large surface area [16]. It has been found that the nanotextured Si solar cells prepared by MACE process via $\mathrm{HF}$ and $\mathrm{AgNO}_{3}$ aqueous solution can reduce the re- 
flection to below $2 \%$ [17]. However, nanotextured Si solar cells prepared using the MACE process suffer from surface recombination and Auger recombination due to their large surface area. This is attributed by the non-uniform heavy etching which limits the short circuit current and the conversion efficiency. Therefore, it is necessary to control the MACE process in order to obtain a uniform shallow nanotextured Si surface that can reduce the surface recombination and increase the cell performance.

In this work, we formulated the nanopyramidal structure from a flat Si (100) wafer and fabricated nanotextured surfaces on microtextured single crystalline Si solar cells using metal-assisted chemical etching. The nanotexturing process is controlled to form shallow nanopores and the PR of the nanotextured Si is significantly reduced in the UV-VIS region of the solar spectrum. The quantum efficiency is also reduced from the nanotextured surface. However, photoluminescence spectra are enhanced and the overall conversion efficiency of the fabricated nanotextured Si solar cells is also improved compared to the reference cell.

\section{EXPERIMENTAL DETAILS}

The micropyramid and nanopyramid surfaces on Si solar cells were formed by alkali solutions of $\mathrm{KOH}$ and $\mathrm{NaOH}$, respectively. P-type boron-doped single crystalline 6-in Si wafers with a specific resistance of $0.5 \sim 3 \Omega \mathrm{cm}$ and a thickness of $200 \pm 5 \mu \mathrm{m}$ were used for the fabrication of the shallow nanotextured solar cells. The detail process flows are illustrated in Fig. 1. A microtexturing process for micropyramid formation was carried out in a $\mathrm{KOH}-$ isopropyl alcohol (IPA) solution at a temperature $80^{\circ} \mathrm{C}$ for 45 min followed by saw damage removal. In order to remove the $\mathrm{K}$ contaminants, the textured wafers were cleaned in $\mathrm{HCl}: \mathrm{H}_{2} \mathrm{O}_{2}: \mathrm{H}_{2} \mathrm{O}$ mixture at $80^{\circ} \mathrm{C}$ for $10 \mathrm{~min}$ and the wafer surfaces were then $\mathrm{H}$ terminated by dilute HF and rinsed with sufficient distilled (DI) water. However, the nanotexturing process for nanopyramid formation was carried out in $1 \% \mathrm{NaOH}$ solution at a temperature of $80^{\circ} \mathrm{C}$ for $10 \mathrm{~min}$ followed by saw damage removal. The samples were sufficiently rinsed with DI water and treated with $6 \% \mathrm{HCl}$ for $15 \mathrm{~min}$ in order to remove the Na residual. After the Na residual removal, the samples were treated with $5 \%$ HF to remove the surface oxide. Finally, a RCA-2 cleaning process was carried out by $\mathrm{HCl}: \mathrm{H}_{2} \mathrm{O}_{2}: \mathrm{H}_{2} \mathrm{O}(1: 1: 6 \mathrm{vol} \%)$ for $10 \mathrm{~min}$ and the formed oxide was further removed by $5 \% \mathrm{HF}$. The samples were then sufficiently rinsed by DI water and also dried by a $\mathrm{N}_{2}$ gun.

Further nanotexturing processes on the micropyramid and nanopyramid surfaces were carried out using a one-step MACE process involving a $\mathrm{HF}: \mathrm{AgNO}_{3}$ solution. For the etching on the microtextured surface, the amount of $\mathrm{AgNO}_{3}$ was $0.005 \mathrm{M}$, the amount of HF was $0.014 \mathrm{M}$, and the etching time was varied. It is important to note that a very low concentration of $\mathrm{HF}$ and $\mathrm{AgNO}_{3}$ solution was used and the cells were etched for a short time because high concentration and long etching time caused over-etching of the microtextured surface which increases the surface recombination [18]. The nanotexturing process on the nanopyramid was performed with the high concentration of $\mathrm{HF}: \mathrm{AgNO}_{3}(5: 0.01 \mathrm{M})$ solution for an etching time of $10 \mathrm{sec}$. After the nanotexturization process, the Ag residuals remaining on the solar cell surfaces were removed by dipping in concentrated $\mathrm{HNO}_{3}$ acid for 3 min and sufficiently rinsing with DI water. The wafers were then treated with a mixture of $\mathrm{HCl}: \mathrm{H}_{2} \mathrm{SO}_{4}: \mathrm{H}_{2} \mathrm{O}$ at a volume ratio of $1: 1: 2$ at $70^{\circ} \mathrm{C}$ for $10 \mathrm{~min}$ in order to remove the HF contaminants remaining after the nanotexturing process. The oxide formed by this process was removed with $10 \%$ HF for 1 $\min$.

The emitter layer was formed using a tube furnace diffusion process and $\mathrm{POCl}_{3}$ liquid was used as the doping source.

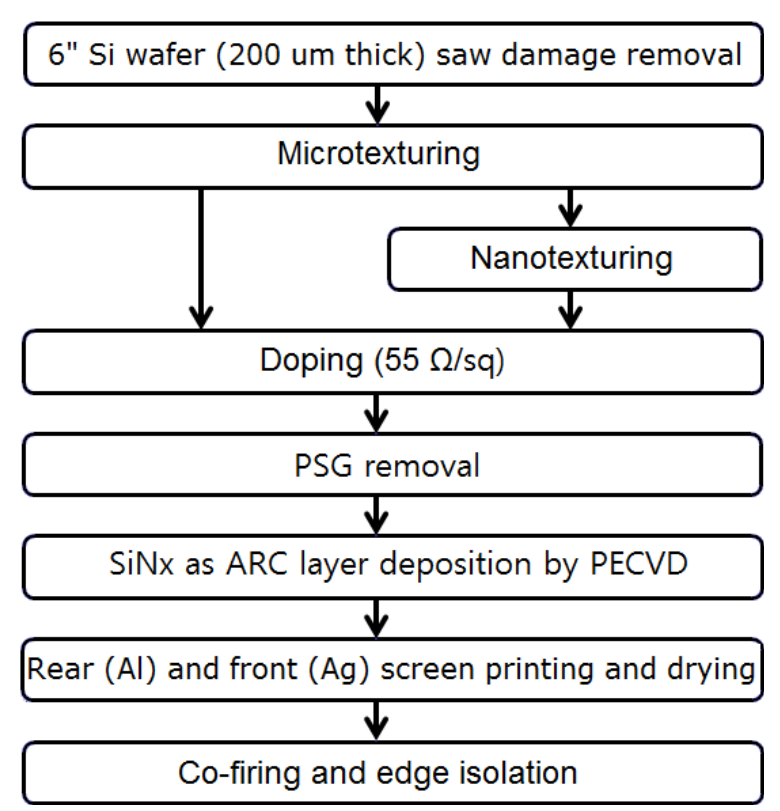

Fig. 1. Experimental process flow diagram of the fabricated Si solar cells with surface nanotexturing process by metal assisted chemical etching.

The doping process was carried out by two steps of the predeposition and the drive-in process under $\mathrm{O}_{2}$ and $\mathrm{N}_{2}$ carrier gases, respectively, in order to obtain a sheet resistance of $55 \Omega$ / sq. During the pre-deposition process that carried out for $10 \mathrm{~min}$ at $750^{\circ} \mathrm{C}$, a $\mathrm{P}_{2} \mathrm{O}_{5}$ layer was formed and worked as a phosphorous dopant source on the $\mathrm{Si}$ solar cell surface. Phosphorous was diffused into the solar cell using the drive-in process at $820^{\circ} \mathrm{C}$ for $10 \mathrm{~min}$ and phosphor-silicate glass (PSG) was formed on the surface. This PSG layer was removed with a $10 \%$ HF solution. After the removal of the PSG layer, an $80 \mathrm{~nm}$ thick $\mathrm{SiN}_{\mathrm{x}}$ layer as an ARC layer was deposited under $\mathrm{SiH}_{4}: \mathrm{NH}_{3}$ :Ar gas for 10 min using plasma enhanced chemical vapor deposition (PECVD). The front silver pattern contact and aluminum back surface field were formed using a screen-printing technique and dried at $200^{\circ} \mathrm{C}$. A co-firing process was then carried out in a belt IR furnace at $400 \sim 850^{\circ} \mathrm{C}$. Finally, the edge isolation process was performed to prevent current leakage.

The fabricated solar cells were characterized using various measurement tools including a field emission scanning electron microscope (FESEM) to study the surface morphology of the cells. The PRs of the textured wafers and the fabricated solar cells were measured using a UV-VIS-NIR spectrophotometer. The p-n junction of the solar cells and Ohmic contact properties were characterized from photoluminescence and electroluminescence images (McScience Co. K3300). The quantum efficiency was measured (ICPE system Co. QEX7) with a Xenon arc lamp that converts the incident photons to currents.

\section{RESULTS AND DISCUSSION}

Figure 2 shows the FESEM images of the nanotextured nanopyramidal structure with the high concentration of $\mathrm{HF}: \mathrm{AgNO}_{3}$ (5:0.01 M) solution for an etching time of $10 \mathrm{sec}$. An Ag MACE process was carried out on the nanopyramidal surface of flat wafer. Ag nanodendrites covered the flat surface and showed the local contact with $\mathrm{Si}$ where the contact potential is derived from the etching process. The surface showed the formation of the nanoporous structure as various nanopits and pyramids with the 

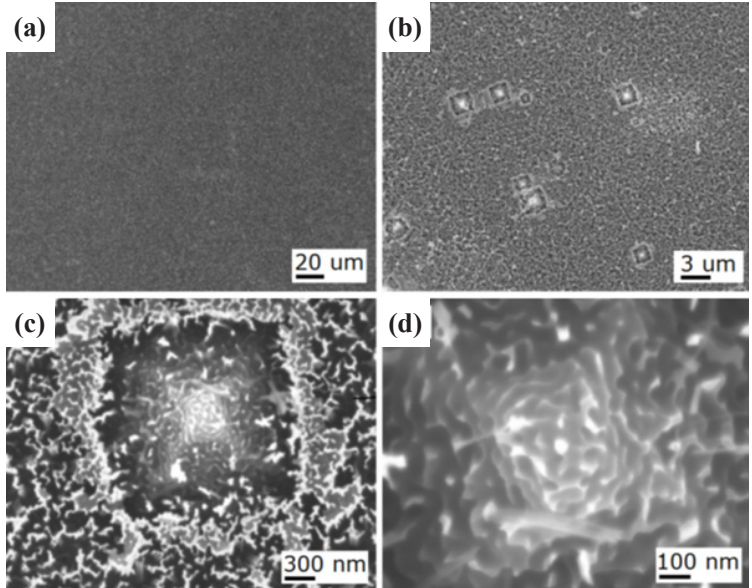

(d)

Fig. 2. FESEM images of formation of the nanotextured nanopyramidal structure by etching with the high concentration of $\mathrm{HF}: \mathrm{AgNO}_{3}$ (5:0.01 M) solution for the etching time of $10 \mathrm{sec}$.
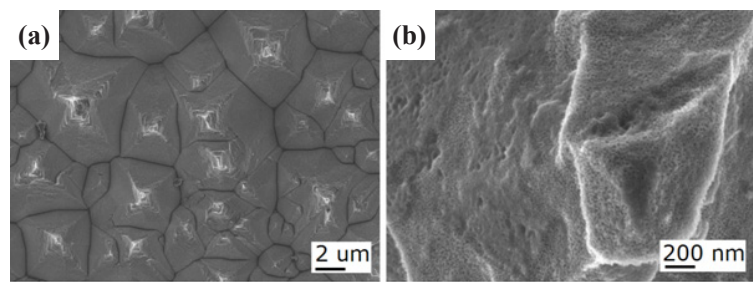

(c)

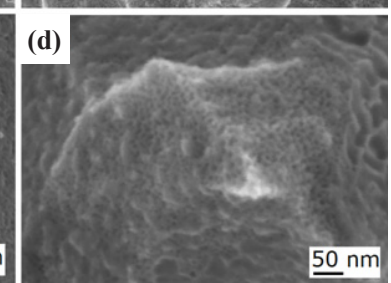

Fig. 3. FESEM images of the nanotextured Si solar cell wafers etched with the concentration of $\mathrm{HF}: \mathrm{AgNO}_{3}(0.14: 0.005 \mathrm{M})$ solution for the etching time of $30 \mathrm{sec}$.

dimension range of $1 \sim 3 \mu \mathrm{m}$. The nanoscale-sized pyramids are observed on the nanoporous surface as shown in Fig. 2(d). This is applicable to the formation of the nanotextured surface on the microtextured wafer.

Figure 3 shows FESEM images of the nanotextured Si solar cell on the microtextured wafers etched using the concentration of $\mathrm{HF}: \mathrm{AgNO}_{3}(0.14: 0.005 \mathrm{M})$ solution with the etching time of 30 sec. The diluted etching solution provides the uniformly nanotextured hillsides with nanopits on micropyramids indicating very shallow etching with a low roughness of the cells for $30 \mathrm{sec}$.

Figure 4 shows FESEM images of the same nanotextured Si solar cell with the etching time of $1 \mathrm{~min}$. The micropyramids were nanoetched and formed roughened nanosurfaces, which were slightly damaged on the top area due to the increased etching process from the non-uniform formation of $\mathrm{Ag}$ dendrites at the top areas.

Figure 5 shows the FESEM images of the same nanotextured Si solar cell with the etching time of $3 \mathrm{~min}$. This sample showed severe damages on the top area of the micropyramids due to the over-etching process resulting in the formation of low dense ultra-small nanospikes similar to nanostructures. The Ag metalassisted nanotexturing process shows the dark gray surfaces of $\mathrm{Si}$ wafers visible to the naked eye. This indicates that a surface
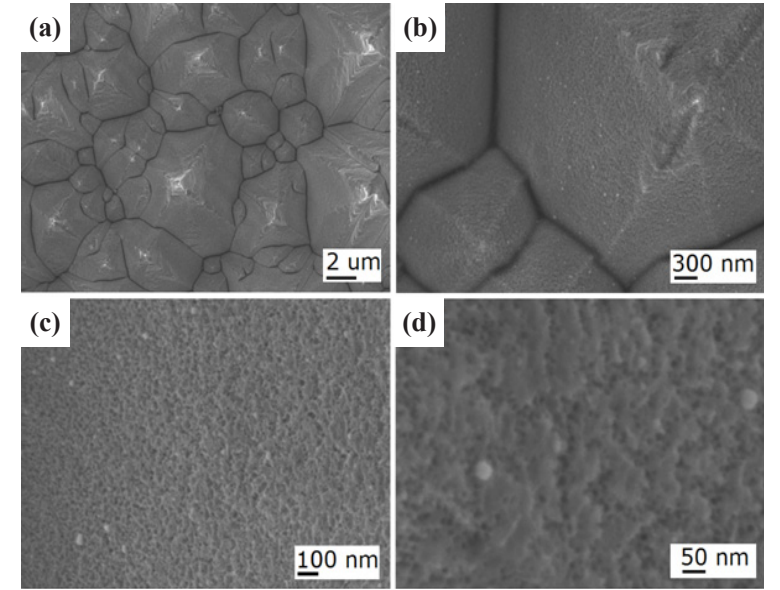

Fig. 4. FESEM images of the nanotextured Si solar cell wafers etched with the concentration of $\mathrm{HF}: \mathrm{AgNO}_{3}(0.14: 0.005 \mathrm{M})$ solution for the etching time of $1 \mathrm{~min}$.
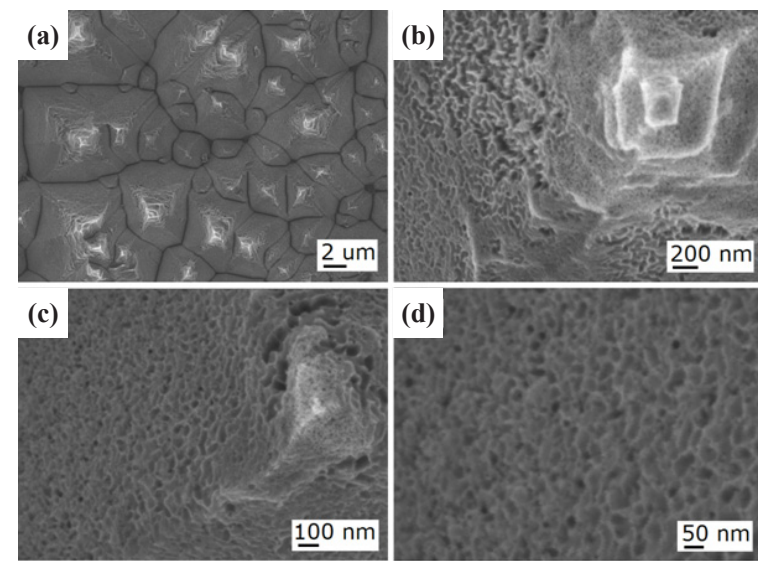

(d)

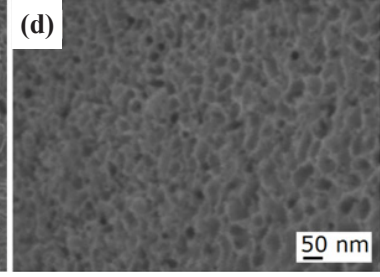

Fig. 5. FESEM images of the nanotextured Si solar cell wafers etched with the concentration of $\mathrm{HF}: \mathrm{AgNO}_{3}(0.14: 0.005 \mathrm{M})$ solution for the etching time of $3 \mathrm{~min}$.

morphology can be transited from nanopits to nanospikes when the etching time is increased from $30 \mathrm{sec}$ to $3 \mathrm{~min}$.

The nanotexturing mechanism of the MACE process has been described in our previous article [18]. The nanotexturing process is regulated by the cathodic and anodic reaction between the etchant solution and $\mathrm{Si}$. The etching rate is increased with high concentration of $\mathrm{HF}: \mathrm{AgNO}_{3}$ solution. The catalytic surface reaction between Ag nanodots and the $\mathrm{Si}$ surface can occur due to the surface plasmon effect. The high concentration of $\mathrm{HF}: \mathrm{AgNO}_{3}$ solution dissolves the Si micropyramidal surface rapidly, even for a small etching time of $10 \mathrm{sec}$. When the etching time is increased, the dissolution of $\mathrm{Si}$ is also increased, and this destroys the micropyramids of the solar cell surfaces. However, the nanotexturing process with the low concentration of the $\mathrm{HF}: \mathrm{AgNO}_{3}$ solution indicates low etching rate. At the etching time of $30 \mathrm{sec}$, the formed nanopits reveal the initiation of the nanotexturing process by the reduction of $\mathrm{Ag}$ ions at the $\mathrm{Ag} / \mathrm{Si}$ interface, resulting in the formation of $\mathrm{SiO}_{2}$ which is dissolved by HF. For the 30 sec etching time, the area between the top and the bottom of the micropyramids is uniformly etched due to the formation of nanopits. At the etching time of $1 \mathrm{~min}$, nanopores are formed due to the confinement of the Ag nanoparticles in the nanopits during the etching process. When the etching time increases, the 

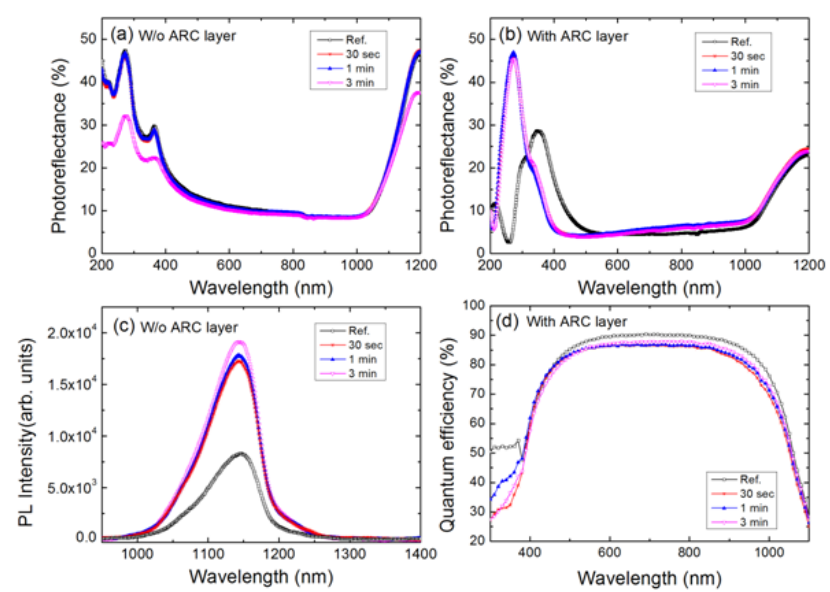

Fig. 6. Nanotextured cell properties of photoreflectance (a) without and (b) with $\mathrm{SiN}_{\mathrm{x}}$ layer, (c) photoluminescence by YAG laser excitation, and (d) internal quantum efficiency.

rate of the cathodic and anodic reaction also increases, which accelerates the hole injection in the $\mathrm{Si}$, while a larger number of the Ag nanoparticles attach to the top of the micropyramids than the valley parts. These Ag nanoparticles further sink more vertically into the Si and over-etch the top of the micropyramids causing non-uniform etching. Therefore, the nanotexturing process can be optimized to a relatively short time and high concentration for a nanopyramidal surface but to a relatively long time and low concentration for a micropyramidal surface. The nanopores formed on the microtextured surfaces of the Si solar cells have the tendency to act as an anti-reflection layer to improve the conversion efficiency [19-21]

Figure 6 shows the photo-reflectance (PR) properties of the nanotextured cell without and with the $\mathrm{SiN}_{\mathrm{x}}$ layer, the photoluminescence (PL) by YAG laser excitation, and the internal quantum efficiency (QE) measured under a Xenon arc lamp for the conversion of incident photons to currents. Figure 6(a) shows the PR of the Ref. and nanotextured Si solar cell samples etched for $30 \mathrm{sec}, 1 \mathrm{~min}$, and $3 \mathrm{~min}$ without an ARC layer. The PR of the nanotextured samples etched for $30 \mathrm{sec}$ and $1 \mathrm{~min}$ is slightly reduced in the UV/VIS region of a wavelength range of 390 700 $\mathrm{nm}$ and is reduced further in the same region for the $3 \mathrm{~min}$ etched sample. The PR of the fabricated nanotextured Si solar cells is significantly reduced in the wavelength ranging from 337 to $596 \mathrm{~nm}$ with an $80 \mathrm{~nm}$ thick $\mathrm{SiN}_{\mathrm{x}}$ anti-reflection coating layer as shown in Fig. 6(b). The cell nanotextured for 3 min shows the lowest $4 \%$ PR in the visible wavelength range of $451 \sim 596 \mathrm{~nm}$. The PR of the nanotextured solar cells in the VIS/IR region of the solar spectrum of the wavelength range of $600 \sim 1,200 \mathrm{~nm}$ is increased more than that of the Ref. The nanotextured cell etched for 3 min has comparatively smaller PR than the cells etched for $30 \mathrm{sec}$ and $1 \mathrm{~min}$, which indicates that a long etching time is better to reduce the PR of Si solar cells. Figure 6(c) shows the PL spectral peak at 1,142 nm of the Si band gap energy region. The nanotextured samples on the microtextured wafers show the enhanced intensities compared to the microtextured Ref. sample. The nanosurface enhances the light extraction from the radiative recombination process by optical pumping. Figure 6(d) shows the internal QEs of the nanotextured and Ref. cells. The microtextured Ref. sample shows a QE of $90.4 \%$ and the nanotextured cells etched for $30 \mathrm{sec}, 1 \mathrm{~min}$, and $3 \mathrm{~min}$ show QEs of about $86.7 \%, 86.8 \%$, and $88 \%$, respectively.

The reduced PR of the nanotextured Si solar cells in the UV/ VIS region of the wavelength of 337 596 nm ensures the nano-
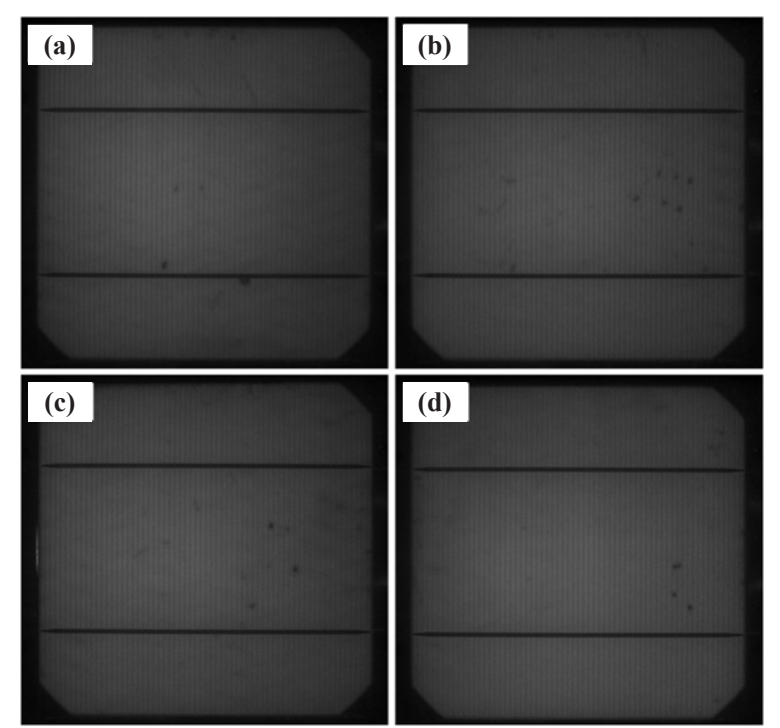

Fig. 7. Photographic photoluminescence images of (a) microtextured Ref. cell and the nanotextured Si solar cells for etching times of (b) 30 sec, (c) $1 \mathrm{~min}$, and (d) $5 \mathrm{~min}$.

texturing effect by the MACE process. The reflectance of the nano/micro-textured solar cells is especially suppressed in the wavelength range of $400 \sim 600 \mathrm{~nm}$, which implies that the nanotextured surface with dense nanopores can act as an ARC layer to improve the light absorption by confining the incident light [22]. The enhanced PL extraction from the nanosurface indicates that the Si nanopores increase the surface area and the corresponding nanosurface recombination. However, the nanosurface-related dangling bonds decrease the internal QE and short circuit current [23]. Furthermore, the absorption of short-wavelength photons due to the nanoporous Si surface causes poor blue response due to the high surface recombination $[24,25]$. Although the nanotextured cells increase surface and Auger recombination, the photogenerated carriers near the Si bandgap contribute to the enhanced light extraction. This indicates that the radiative photogeneration can enhance $p-n$ junction property.

Figure 7 shows the photographic PL images of the Ref. and the nanotextured Si solar cells etched for $30 \mathrm{sec}, 1 \mathrm{~min}$, and $3 \mathrm{~min}$. The PL image of the Ref. cell is darker than the nanotextured Si solar cells. The brightness of the nanotextured cells is slightly increased when increasing etching time. Several black spots can also be observed in the PL images where no light absorption or emission occurs.

Figure 8 shows the photographic EL images of the Ref. and the nanotextured Si solar cells etched for $30 \mathrm{sec}, 1 \mathrm{~min}$, and $3 \mathrm{~min}$. The EL images are bright along the bus bars. The nanotextured cells are brighter than the Ref. cell, which indicates the better Ohmic or shunt property of the p-n junction. Furthermore, the overall brightness in the EL image of the cell etched for $3 \mathrm{~min}$ is greater than that of the other cells. Several black spots can also be observed in the EL images which are correlated to the shunt resistance problem.

The enhanced PL and EL in the nanotextured Si solar cells indicate that the electron-hole recombination becomes radiative as shown in the PL emission spectra. The light extraction from the nanosurface can be enhanced due to the reduced wave optical impedance [26]. The wave diffraction from the nanosurfaces can form the delocalized carrier distribution in the depletion layer of the $\mathrm{p}-\mathrm{n}$ junction. However, the dangling bonds related to the nonradiative recombination from the nanosurfaces can 

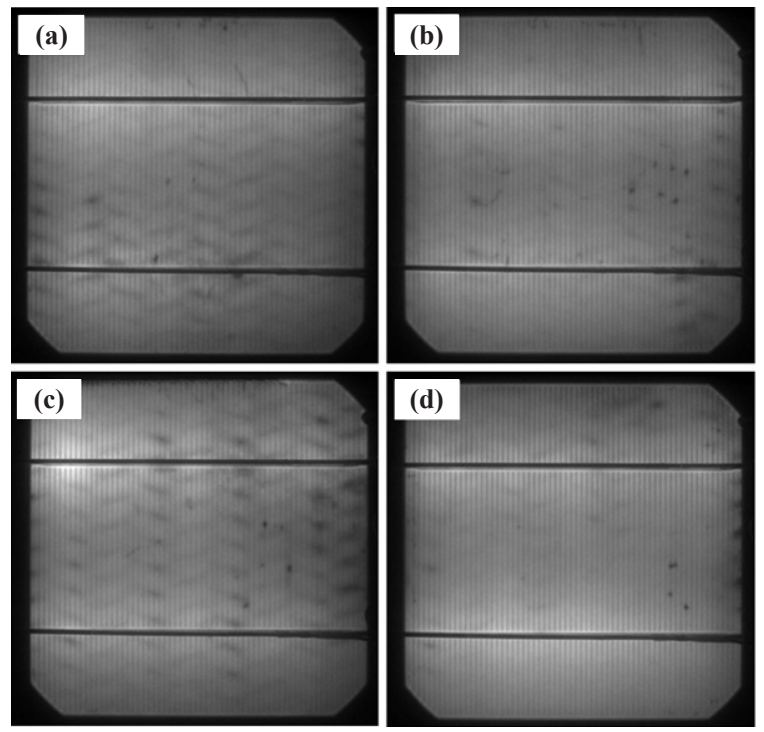

Fig. 8. Photographic electroluminescence images of (a) microtextured Ref. cell and the nanotextured Si solar cells for etching times of (b) $30 \mathrm{sec}$, (c) $1 \mathrm{~min}$, and (d) $5 \mathrm{~min}$.

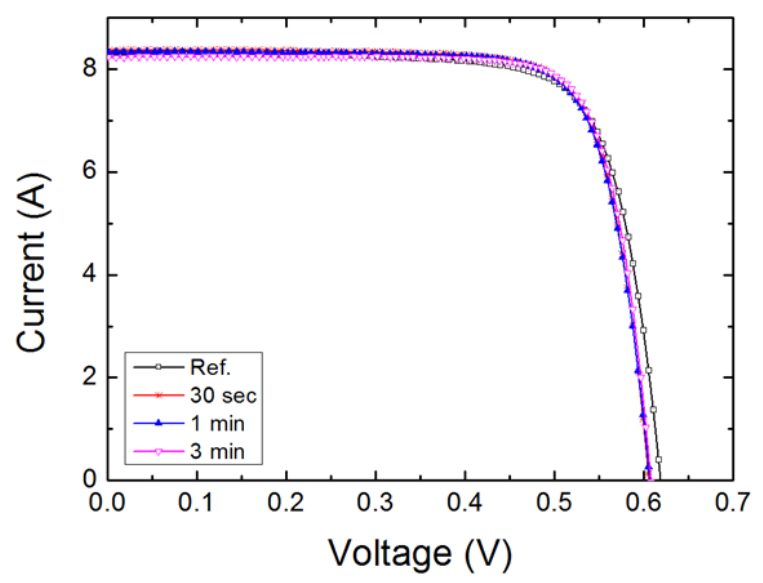

Fig. 9. Current-voltage curves of the fabricated Si solar cells with the inclusion of the surface nanotexturing for various etching times.

suppress the light emission, which is related to the conversion efficiency [27]. Therefore, the nanotextured surfaces of the $\mathrm{Si}$ solar cells show the trade-off relation between the surface nonradiative recombination and the nanostructural light extraction. The improved EL emission by introducing the nanotexturing process is the reverse process of the photovoltaic effect and is reflected in the conversion efficiency of Si solar cells.

The current-voltage characteristics of the fabricated Ref. and nanotextured cells measured using a solar simulator under the conditions of $100 \mathrm{~mW} / \mathrm{cm}^{2}$ and $\mathrm{AM} 1.5$ irradiation at $25^{\circ} \mathrm{C}$ are shown in Fig. 9 and summarized in Table 1. The conversion efficiency of the Ref. cell is $16.2 \%$ with the fill factor of $\mathrm{FF}=75.7 \%$, the open circuit voltage of $\mathrm{V}_{\mathrm{oc}}=0.618 \mathrm{~V}$, the short circuit current of $I_{s c}=8.33 \mathrm{~A}$, the series resistance of $R_{s}=8 \mathrm{~m} \Omega$, and the shunt resistance of $\mathrm{R}_{\mathrm{sh}}=4.5 \Omega$. The nanotextured cell with the etching time of $30 \mathrm{sec}$ showed the efficiency of $16.5 \%$ with $\mathrm{FF}=77.7 \%, \mathrm{~V}_{\mathrm{oc}}=0.605$ $V, I_{s c}=8.37 \mathrm{~A}, R_{s}=7 \mathrm{~m} \Omega$, and $R_{s h}=8 \Omega$. Similarly, the conversion efficiency of the cell etched for $1 \mathrm{~min}$ is $16.4 \%$ with $\mathrm{FF}=77.8 \%, \mathrm{~V}_{\mathrm{oc}}$ $=0.606 \mathrm{~V}, \mathrm{I}_{\mathrm{sc}}=8.33 \mathrm{~A}, \mathrm{R}_{\mathrm{s}}=7 \mathrm{~m} \Omega$, and $\mathrm{R}_{\mathrm{sh}}=8.5 \Omega$. For 3 min-etching time, the nanotextured cell showed the highest conversion ef-
Table 1. I-V characteristics of the Ref. and shallow nanotextured Si solar cell. The overall conversion efficiency of the shallow nanotextured Si solar cells is improved compared to the Ref. cell.

\begin{tabular}{ccccccc}
\hline Samples & Eff. [\%] & $\mathrm{V}_{\text {oc }}[\mathrm{V}]$ & $\mathrm{I}_{\mathrm{sc}}[\mathrm{A}]$ & $\mathrm{FF}[\%]$ & $\mathrm{R}_{\mathrm{s}}[\Omega]$ & $\mathrm{R}_{\text {sh }}[\Omega]$ \\
\hline \hline Ref. & $16.1 \pm 0.10$ & 0.618 & 8.33 & 75.7 & 0.008 & 4.5 \\
\hline $30 \mathrm{sec}$ & $16.4 \pm 0.15$ & 0.605 & 8.37 & 77.7 & 0.007 & 8.0 \\
\hline $1 \mathrm{~min}$ & $16.3 \pm 0.17$ & 0.606 & 8.33 & 77.8 & 0.007 & 8.5 \\
\hline 3 min & $16.6 \pm 0.12$ & 0.607 & 8.23 & 79.0 & 0.007 & 10 \\
\hline
\end{tabular}

ficiency of $16.6 \%$ with $\mathrm{FF}=79 \%, \mathrm{~V}_{\mathrm{oc}}=0.607 \mathrm{~V}, \mathrm{I}_{\mathrm{sc}}=8.23 \mathrm{~A}, \mathrm{R}_{\mathrm{s}}=7 \mathrm{~m} \Omega$, and $R_{\text {sh }}=10 \Omega$. The above results reveal that the FF and conversion efficiency of the nanotextured Si solar cells are greater than those of the Ref. cell.

The overall conversion efficiency of the nanotextured Si solar cells is improved and, especially, the fill factors are strongly improved with enhanced shunt resistances. This electrical behavior can be assumed to be the change of the depletion capacitance with alternating bias, which gives direct evidence of charge mobility [28]. Similarly, the change of optical biasing from ray optics to wave optics can influence the capacitance in the depletion region and the optical forward bias can be reduced in the photovoltaic process. The photoelectric effect can be analyzed by the photocurrent measurement [29]. The wavelength dependent effect of the external quantum efficiency on the photovoltaic property shows similar spectral behavior to that of the photoconductance measured by photoconductive atomic force microscopy [30]. Therefore, the nanotextured cells could not improve the short circuit current and open circuit voltage due to the poor blue response and large surface recombination, but they can be stabilized by reducing the optically induced forward bias in the p-n junction.

\section{CONCLUSIONS}

A nanotexturing process was performed on the flat surface of a $\mathrm{Si}$ wafer and further applied to the microtextured surfaces of 6 -in $\mathrm{Si}$ solar cell wafers using a MACE process of $\mathrm{HF} / \mathrm{AgNO}_{3}$ solutions in order to obtain multi-scale textured surface. The nanotexturing process on the flat wafer showed the nanopyramidal structures, while the nanotexturing process on the microtextured wafer showed a nanosurface hillside of micropyramids. The transition from nanopits to interconnected nanopores was formed by increasing the etching time from $30 \mathrm{sec}$ to $3 \mathrm{~min}$. The blue responses in the QE of the nanotextured cells etched for $30 \mathrm{sec}$ and $1 \mathrm{~min}$ were enhanced, and the cell nanotextured for $3 \mathrm{~min}$ showed improved QE in the VIS/IR region. The nanotextured cell showed higher conversion efficiencies than those of the Ref. cell. However, the reduced $\mathrm{I}_{\mathrm{sc}}$ and $\mathrm{V}_{\mathrm{oc}}$ suggest that surface recombination should be reduced by a better passivation for the nanotextured Si solar cells. In conclusion, the nanotexturing process is useful for achieving higher conversion efficiency and enhancing the shunt property with a high fill factor in the Si solar cell with the reservation of the strong surface passivation on the nanosurface.

\section{ACKNOWLEDGMENT}

This work was supported by the Small \& Medium Business Technology Development Program of the Korea Institute of Energy Technology and Planning (KETEP) grant, funded by the Korean government (SMTECH-S2126338) and the Nano-Material Technology Development Program through the National Re- 
search Foundation of Korea (NRF) funded by Ministry of Science, ICT and Future Planning (2009-0082580).

\section{REFERENCES}

[1] M. A. Green and M. J. Keevers, Prog. Photovolt: Res. Appl., 3189 (1995). [DOI: http://dx.doi.org/10.1002/pip.4670030303]

[2] P. Papet, O. Nichiporuk, A. Kaminski, Y. Rozier, J. Kraiem, J. F. Lelievre, A. Chaumartin, A. Fave, and M. Lemiti, Sol. Energ. Mat. Sol. Cells, 90, 2319 (2006). [DOI: http://dx.doi.org/10.1016/ j.solmat.2006.03.005]

[3] E. Vazsonyi, K. De Clercq, R. Einhaus, E. Van Kerschaver, K. Said, J. Poortmans, J. Szlufcik, J. Nijs, Sol. Energ. Mat. Sol. Cells, 57, 179 (1999). [DOI: http://dx.doi.org/10.1016/s09270248(98)00180-9]

[4] J. Choi, B. Parida, H. Y. Ji, S. Park, and K. Kim, J. Nanosci. Nanotechnol., 12, 5619 (2012). [DOI: http://dx.doi.org/10.1166/ jnn.2012.6306]

[5] J. Choi, B. Parida, H.Y. Ji, S. Park, and K. Kim, J. Nanosci. Nanotechnol., 12, 5552 (2012). [DOI: http://dx.doi.org/10.1166/ jnn.2012.6400]

[6] B. Parida, J. Choi, G. Lim, K. Kim, and K. Kim, J. Nanomater. 2013, 1 (2013). [DOI: http://dx.doi.org/10.1155/2013/953790]

[7] H. Y. Ji, J. Choi, G. Lim, B. Parida, K. Kim, J. H. Jo, and H. S. Kim, J. Nanosci. Nanotechnol., 13, 7806 (2013). [DOI: http://dx.doi. org/10.1166/jnn.2013.8119]

[8] H. Lv, H. Shen, Y. Jiang, C. Gao, H. Zhao, and J. Yuan, Appl. Surf. Sci., 258, 5451 (2014). [DOI: http://dx.doi.org/10.1016/ j.apsusc.2012.02.033]

[9] J. Oh, H. C. Yuan, and H. M. Branz, Nature Nanotechnol., 7, 743 (2012). [DOI: http://dx.doi.org/10.1038/nnano.2012.166]

[10] K. S. Do, M. G. Kang, J. J. Park, G. H. Kang, J. M. Myoung, and H. Song, Jpn. J. Appl. Phys., 52, 092301 (2013). [DOI: http://dx.doi. org/10.7567/jjap.52.092301]

[11] B. K. Nayak, V. Iyengar, and M. C. Gupta, Prog. Photovolt: Res. Appl., 19, 631 (2011). [DOI: http://dx.doi.org/10.1002/pip.1067]

[12] M. Moreno, D. Daineka, and P. R. I Cabarrocas, Sol. Energ. Mat. Sol. Cells, 94, 733 (2010). [DOI: http://dx.doi.org/10.1016/ j.solmat.2009.12.015]

[13] C. Battaglia, K. Soderstrom, J. Escarre, F. J. Haug, D. Domine, P. Cuony, M. Boccard, G. Bugnon, C. Denizot, M. Despeisse, A Feltrin, and C. Ballif, Appl. Phys. Lett., 96, 213504 (2010). [DOI: http://dx.doi.org/10.1063/1.3432739]

[14] D. Z. Dimitrov, C. H. Lin, C. H. Du, and C. W. Lan, Phys. Status
Solidi A, 12, 2926 (2011). [DOI: http://dx.doi.org/10.1002/ pssa.201127150]

[15] Z. Huang, N. Geyer, P. Werner, J. D. Boor, and U. Gosele, Adv. Mater., 23, 285 (2011). [DOI: http://dx.doi.org/10.1002/ adma.201001784]

[16] D. Z. Dimitrov and C. H. Du, Appl. Surf. Sci., 266, 1 (2013). [DOI: http://dx.doi.org/10.1016/j.apsusc.2012.10.081]

[17] S. K. Srivastava, D. Kumar, P. K. Singh, M. Kar, M. Husain, and V. Kumar, Sol. Energ. Mat. Sol. Cells, 94, 1506 (2010). [DOI: http:// dx.doi.org/10.1016/j.solmat.2010.02.033]

[18] B. Parida, J. Choi, G. Lim, S. Park, and K. Kim, J. Nanosci. Nanotechnol., 14, 9224 (2014). [DOI: http://dx.doi.org/10.1166/ jnn.2014.10129]

[19] P. Panek, M. Lipinski, and H. Czternastek, Opto-Electr. Rev., 8, 57 (2000). [DOI: http://dx.doi.org/10.1016/s0921-5107(02)007201]

[20] J. Y. Jung, Z. Guo, S. W. Jee, H. D Um, K. T. Park, and J. H. Lee, Opt. Express, 18, A286 (2010). [DOI: http://dx.doi.org/10.1364/ oe.18.00a286]

[21] Y. J. Cho and H. S. Chang, Phys. Status Solidi C, 9, 2097 (2012). [DOI: http://dx.doi.org/10.1002/pssc.201200093]

[22] J. Xiao, L. Wang, X. Li, X. Pi, and D. Yang, Appl. Surf. Sci., 257, 472 (2010). [DOI: http://dx.doi.org/10.1016/j.apsusc.2010.07.014]

[23] C. Chen, R. Jia, H. Yue, H. Li, X. Liu, D. Wu, W. Ding, T. Ye, S. Kasai, H. Tamotsu, J. Chu, and S. Wang, J. Appl. Phys., 108, 094318 (2010). [DOI: http://dx.doi.org/10.1063/1.3493733]

[24] F. Toor, H. M. Branz, M. R. Page, K. M. Jones, and H. C. Yuan, Appl. Phys. Lett., 99, 103501 (2011). [DOI: http://dx.doi. org/10.1063/1.3636105]

[25] H. C. Yuan, V. E. Yost, M. R. Page, P. Stradins, D. L. Meier, and H. M. Branz, Appl. Phys. Lett., 95, 123501 (2009). [DOI: http:// dx.doi.org/10.1063/1.3231438]

[26] K. Kim and J. Choi, J. Appl. Phys., 105, 033103 (2009). [DOI: http://dx.doi.org/10.1063/1.3075828]

[27] M. A. Tischler, R. T. Collins, J. H. Stathis, and J. C. Tsang, Appl. Phys. Lett., 60, 639 (1992). [DOI: http://dx.doi. org/10.1063/1.106578]

[28] D. K. Kim, Y. J. Oh, S. H. Kim, K. J. Hong, H. Y. Jung, H. J. Kim, and M. S. Jeon, Trans. Electr. Electron. Mater., 14, 177 (2013). [DOI: http://dx.doi.org/10.4313/teem.2013.14.4.177]

[29] B. Parida, H. Y. Ji, G. H. Lim, S. Park, and K. Kim, J. Renew. Sust. Energ., 6, 053120 (2014). [DOI: http://dx.doi. org/10.1063/1.4897656]

[30] J. Heo, Trans. Electr. Electron. Mater., 14, 160 (2013). [DOI: http://dx.doi.org/10.4313/TEEM.2013.14.3.160] 